\title{
KONFIGURASI POLITIK HUKUM PERBANKAN SYARIAH DI INDONESIA
}

\author{
Djawahir Hejazziey \\ Fakultas Syariah dan Hukum UIN Syarif Hidayatullah Jakarta \\ Jl. H. Juanda 95, Ciputat, Jakarta \\ E-mail: djawahirhejazziey@gmail.com
}

\begin{abstract}
The Political Configuration of the Shariah Banking in Indonesia. Islamic law applies to Muslims wherever they are, whatever their nationality. But the National law is the law applicable to a particular nation, in a particular national state. In Indonesia's case, the National law also means the law developed by the Indonesian people, after Indonesia became an independent country and in force for the Indonesian people as successor to the old colonial law. Thus, Islamic law should be used now instead of the colonial law, which is no longer relevant to Islamic values. Shariah banking law is a product of National law which is adopted from Quranic and Sunnah values. Therefore, in the realm of business law, the Islamic law is a truly National law.
\end{abstract}

Keywords: configuration, law, politics, Islamic banking

\begin{abstract}
Abstraksi: Konfigurasi Politik Hukum Perbankan Syariab di Indonesia. Hukum Islam berlaku bagi orang Islam di manapun ia berada dan apapun kebangsaannya. Sedangkan hukum Nasional adalah hukum yang berlaku bagi bangsa tertentu, di suatu negara tertentu. Dalam kasus Indonesia, hukum Nasional juga berarti hukum yang dibangun oleh bangsa Indonesia setelah Indonesia merdeka dan berlaku bagi penduduk Indonesia sebagai pengganti hukum kolonial. Jadi, semestinya hukum Islam yang digunakan sekarang juga sebagai pengganti hukum kolonial, yang tidak lagi relevan dengan nilai Islam. Hukum perbankan syariah merupakan produk hukum Nasional yang diadopsi dari nilai Alquran dan Sunah. Untuk itu, dalam ranah hukum bisnis, hukum Islam inilah yang benar-benar telah menjadi hukum Nasional.
\end{abstract}

Kata Kunci: konfigurasi, hukum, politik, perbankan syariah

\section{Pendahuluan}

Ketika membincang politik hukum perbankan syariah, maka akan terbayang dalam benak bahwa hukum adalah sesuatu yang lemah. Artinya, hukum dalam posisi sebagai obyek dari politik, dan politik sebagai subyek yang memberikan pengaruh kepada hukum. ${ }^{1}$ Hal ini menunjukkan bahwa hukum adalah

${ }^{1}$ Hukum adalah hasil tarik-menarik pelbagai kekuatan politik yang mengejawantah dalam produk hukum. Dalam hal ini Satjipto Raharjo menyatakan, bahwa hukum adalah instrumentasi dari putusan atau keinginan politik, sehingga pembuatan undang-undang sarat dengan kepentingan-kepentingan tertentu, dan dengan demikian medan pembuatan undang-undang menjadi medan perbenturan dan pergumulan kepentingan-kepentingan. Badan pembuatundang-undang akan mencerminkan konfigurasi kekuatan dan kepentingan yang ada dalam masyarakat. Konfigurasi kekuatan dan kepentingan dalam badan pembuat undang-undang menjadi penting karena pembuatan undang-undang modern bukan sekadar merumuskan materi hukum secara baku berikut rambu-rambu yuridisnya, melainkan membuat putusan politik terlebih dahulu. Di samping konfigurasi kekuatan dan kepentingan dalam badan pembuat undang-undang, intervensi- produk politik, sehingga ketika membahas politik hukum cenderung mendiskripsikan pengaruh politik terhadap hukum atau pengaruh sistem politik terhadap pembangunan hukum menuju perubahan iklim politik yang membawa tatanan pemerintahan ke arah yang lebih baik, seperti halnya bangsa Indonesia ini yang semakin tumbuh dewasa dalam penerapan hukum ${ }^{2}$ dan demokrasi, ${ }^{3}$ baik penegakan hukum, persamaan

intervensi dari luar tidak dapat diabaikan dalam pembentukan undangundang. Intervensi tersebut dilakukan terutama oleh golongan yang memiliki kekuasaan dan kekuatan, baik secara sosial, politik, maupun ekonomi. Jazuni, Legislasi Hukum Islam di Indonesia (Bandung: Citra Aditya Bakti, 2005), cetakan I, h. 9.

${ }^{2}$ Sri Wahyuni, "Politik Hukum Islam di Indonesia (Studi terhadap Legislasi Kompilasi Hukum Islam)", Jurnal Mimbar Hukum No. 59 T XIV, al-Hikmah, 2003, h. 74.

${ }^{3}$ Esensi demokrasi adalah proses, karenanya ia merupakan sistem yang dinamis menuju ke arah yang lebih baik dan maju dibandingkan dengan yang sedang dialami masyarakat (negara) atau sebelumnya. Nurcholis Madjid, "Demokrasi dan Demokratisasi di Indonesia", dalam Elsa Pedi Taher (ed.), Demokratisasi Politik, Budaya dan Ekonomi (Jakarta: Paramadina, 1994), cetakan I, h. 203. 
hukum, ${ }^{4}$ hak asasi manusia, ${ }^{5}$ pemerataan sosial dan sebagainya. Bellfroid mendefinisikan rechtpolitiek yaitu proses pembentukan ius constitutum (hukum positif) dari ius constituendum (hukum yang akan dan harus ditetapkan) untuk memenuhi kebutuhan perubahan dalam kehidupan masyarakat. Politik hukum terkadang juga dikaitkan dengan kebijakan publik (public policy), yang menurut Thomas Dye yakni, "Whatever the government choose to do or not to do". Politik hukum juga didefinisikan sebagai pembangunan hukum. ${ }^{6}$

Hukum memiliki inherenitas yang besar dengan pelbagai aspek kehidupan, yakni sistem ideologi Negara, sistem sosial, sistem politik, sistem ekonomi, sistem hukum, dan sistem budaya, baik budaya lokal maupun regional, bahkan global. Karena adanya inherenitas tersebut sehingga banyak faktor-faktor yang mempengaruhi terhadap pembentukan hukum. Ketika dibentuk hukum perbankan syariah terdapat pro dan kontra di dalam masyarakat, ada yang menghendaki pentingnya dibentuk dan ada pula yang mengatakan tidak penting dengan adanya hukum perbankan syariah. Juru bicara partai Fraksi PDS Retna Rosmanita Situmorang mengatakan bahwa hal-hal yang berkaitan dengan perbankan syariah telah diatur dalam UU Republik Indonesia No. 10 Tahun 1998, sehingga tidak perlu lagi dibuatkan UU khusus yang mengatur mengenai kegiatan perbankan syariah. ${ }^{7}$

Dalam politik hukum perbankan syariah, elit politik Islam memiliki daya tawar yang kuat dalam

${ }^{4}$ Persamaan di depan hukum bagi seluruh warga, ini berlaku umum (lex generalis). Sedangkan semua penduduk diberi hak untuk memeluk dan menjalankan ibadah sesuai dengan agamanya masing-masing, ini berlaku khusus (lex spesialis). Ada kekhususan hukum untuk pemeluk agama tertentu. Ismail Suny, "Sekitar UUPA" dalam Buku Peradilan Agama dalam Wadah Negara Pancasila yang disusun oleh Zuffran Sabrie, (Jakarta: Pustaka Antara, 1990), cetakan I, h. 114.

5 Di Indonesia penghormatan atas hak-hak asasi manusia telah dijamin oleh Pancasila dan Undang-Undang Dasar 1945, sebagai pandangan hidup, falsafah, dan dasar konstitusional bagi Negara Kesatuan RI. Walaupun perwujudan secara materiil dan formil baru ada setelah dikeluarkannya undang-undang No. 39 Tahun 1999 tentang HAM dan Undang-undang No. 26 Tahun 2000 tentang Pengadilan HAM. Undang-undang tersebut dikeluarkan sebagai salah satu rangkaian rencana aksi Nasional Hak Asasi Manusia berdasarkan Keputusan Presiden No. 129 tahun 1998. Sebagaimana diketahui, keluarnya undang-undang tersebut setelah pelbagai peristiwa kekerasan terjadi di Indonesia terutama pada masa pemerintahan Orde Baru, seperti kasus Tanjung Priok, Tim-tim, Semanggi dan sebagainya. Kasus-kasus tersebut sampai saat ini masih dalam proses penyelesaian. Paling tidak ada dua kendala utama dalam penyelesaian kasus-kasus HAM di masa lalu, yaitu kendala teknis prosedural yang menyangkut pembuktian secara hukum dan kendala politis yang ditandai oleh adanya kekuatan yang besar untuk menghambat upaya penyelesaian melalui pengadilan. Moh. Mahfud MD, Politik Hukum Hak Azasi Manusia di Indonesia", Pidato Pengukuhan dalam Jabatan Guru Besar, Universitas Islam Indonesia Yogyakarta, 23 September 2000.

${ }^{6}$ Sri Wahyuni, "Politik Hukum Islam di Indonesia", h. 74.

7 Sri Wahyuni, "Politik Hukum Islam di Indonesia", h. 76. interaksi politik, pengembangan hukum Islam dalam suprastruktur politikpun memiliki peluang yang sangat besar. ${ }^{8}$ Sebaliknya, ketika pada masa penjajahan Belanda, posisi hukum Islam sangat termarjinalkan. Hukum Islam hanya dipandang sebagai hukum apabila diresepsi ke dalam hukum Adat, itu pun dalam strata ketiga setelah hukum Eropa dan hukum Adat orang Timur Asing (Arab, China, dan India). ${ }^{9}$ Indonesia yang merupakan negara jajahan Belanda, telah mengalami masa berlangsungnya proses introduksi dan proses perkembangan sistem hukum asing ke dalam hukum masyarakat pribumi. ${ }^{10}$ Jadi, bahwa dalam pembentukan hukum perbankan syariah dikelilingi oleh banyak faktor adalah sesuatu yang tidak dapat dielakkan lagi.

Pada awalnya, politik hukum Islam Indonesia dalam hal pembangunan hukum Nasional, masih dipengaruhi oleh teori receptie yang dikembangkan oleh Snouck Horgronye. Namun pada akhir masa pemerintahan Orde Baru teori receptie mulai berkurang pengaruhnya dan bahkan mati, terbukti dengan telah diterimanya hukum Islam secara bulat sebagai hukum positif, yaitu dengan dimasukkannya Peradilan Agama dalam kekuasaan yudikatif, dihapusnya fiat eksekusi atas putusan Peradilan Agama, tidak ada lagi hak opsi dalam kewarisan Islam, dan diterapkannya hukum ekonomi Islam, serta diperluasnya kewenangan Peradilan Agama. Namun demikian masih ada sebagian elit politik yang phobia terhadap pemberlakuan Hukum Islam. ${ }^{11}$

Seorang ahli hukum Austria, Eugen Ehrlich, mengemukakan bahwa pengaruh hukum di dalam masyarakat harus dilakukan dengan pendekatan hukum yang hidup dalam masyarakat itu sendiri. Artinya bahwa "hukum yang baik adalah hukum yang sesuai dengan hukum yang hidup di dalam masyarakat". Teori ini berpangkal pada perbedaan antara hukum positif dengan hukum yang hidup (living law) dalam masyarakat. Dia menyatakan dalam hukum positif hanya akan efektif apabila selaras dengan hukum yang hidup dalam masyarakat, yang dalam istilah antropologi dikenal dengan pola-pola kebudayaan (culture patterns). ${ }^{12}$

Eugen Ehrlich menganjurkan untuk mengadakan pembaruan hukum melalui perundang-undangan dengan kesadaran untuk memperhatikan kenyataan yang hidup dalam masyarakat. Kenyataan-kenyataan

${ }^{8}$ Cik Hasan Bisri, "Transformasi Hukum Islam ke dalam Sistem Hukum Nasional", Jurnal Mimbar Hukum No. 56 Thn XIII (Jakarta: al-Hikmah, 2002), h. 31.

${ }_{9}$ Cik Hasan Bisri, "Transformasi Hukum Islam", h. 32.

${ }^{10}$ Sri Wahyuni, "Politik Hukum Islam di Indonesia", h. 80.

11 http://aanaboodzforlife.com/2010/02/sistem-perbankan-syari$\%$ E2\%80\%99ah-dalam-perspektif-politik-hukum-indonesia-padasaat-ini (Diakses pada tanggal, 12 Maret 2010).

12 Soejono Soekanto, Pokok-pokok Sosiologi Hukum, (Jakarta: Rajawali, 1991), h. 36. 
tersebut dinamakan "living law dan just law" yang meru-pakan "inner order" dari pada masyarakat mencerminkan nilai-nilai yang hidup di dalamnya. Jika ingin diadakan perubahan hukum atau membuat suatu undang-undang agar hukum atau undang-undang yang dibuat itu dapat diterima dan berlaku secara efektif di dalam kehidupan masyarakat, maka suatu hal yang patut diperhatikan adalah hukum yang hidup dalam masyarakat itu. ${ }^{13}$ Jika hal itu tidak mendapat perhatian, maka akibatnya hukum tidak bisa berlaku efektif, bahkan akan mendapat tantangan.

\section{Embrio Hukum Perbankan Syariah}

Perjuangan politik hukum perbankan syariah merupakan bagian usaha penegakan dalam penerapan syariat Islam di Indonesia yang dilakukan oleh bangsa Indonesia, khususnya umat Islam. Usaha-usaha ini sebetulnya telah lama diformat melalui Piagam Jakarta, namun selalu mengalami kegagalan.

Kendatipun usaha-usaha formalisasi syariat Islam sering mengalami kegagalan ternyata umat Islam tidak berhenti sampai di situ, memuncaknya dalam Sidang Konstituante 1959. Dalam forum itu, seluruh partai Islam memperjuangkan Islam sebagai dasar Negara yang artinya syariat Islam berlaku tidak hanya pada umat Islam, tetapi seluruh rakyat Indonesia. Pada akhirnya perjuangan ini pun menjadi kandas, karena suara pendukung Islam sebagai dasar Negara masih lebih kecil dari suara yang menolaknya, walaupun umat Islam disebut sebagai mayoritas di Indonesia. ${ }^{14}$ Ini memberikan indikasi bahwa umat Islam mempunyai keinginan yang besar untuk memberlakukan syariat Islam di Indonesia.

Jika memperhatikan politik Islam dalam kontek kekinian, bahwa sebagian besar negara-negara muslim lebih diwarnai oleh sistem Barat beserta instrumeninstrumennya. Padahal Islam memiliki sistem dan corak tersendiri dalam menata pemerintahan. Interaksi peradaban yang besar antara Barat dan Islam memberikan pengaruh kepada sejumlah intelektual muslim untuk menerima alternatif yang ditawarkan oleh Barat dalam politik, ketimbang mempertahankan sistem yang sudah ada yang telah teruji kebenaran dan keampuhannya. ${ }^{15}$

Negara-negara Barat saat ini, selalu dihantui oleh tidak hanya berdirinya kekhalifahan Islam, tetapi

${ }^{13}$ W. Fridman, Legal Theory, Edisi ke 3 (Steven and Sons Limited), h. 52 .

${ }^{14}$ M. Dawam Rahardjo, dalam Kata Pengantar Buku Adiwarman Karim, Bank Islam Analisis Fiqih dan Keuangan, h. xiii.

${ }^{15}$ Daud Rasyid, Reformasi Republik Sakit Peluang dan Tantangan Penerapan Syariat Islam Pasca Kejatuhan Soeharto (Bandung, Syamil, 2006), Cet. I, h. 82. juga dihantui oleh sebuah negara yang berdasarkan Islam sebagai asas ideologi. Mereka berusaha sekuat tenaga menghalang-halangi dan menekan negara Islam yang sudah berdiri, dikhawatirkan pula akan menular terbentuknya negara baru yang berdasarkan Islam sebagai asas ideologi.

Untuk itu, Barat mempunyai kepentingan menolak konsep Negara Islam melalui ide dan pemikiran yang dilontarkan oleh tokoh-tokoh umat Islam sendiri yang telah terkontaminasi oleh pendidikan dan pemikiran Barat. Dalam tataran pemikiran, Barat telah berhasil mencetak kaum intelektual yang telah siap mengamini dan menjadi juru bicara Barat, sengaja maupun tidak, untuk tidak menerima pendirian Negara Islam dengan alasan apapun. Mereka memang lebih akrab dengan pemikiran Barat yang liberalis dari pada metode Alquran dan Hadis. Bagi mereka mempunyai kemudahan dalam menggulir pemikirannya, karena di samping mereka hidup di tengah-tengah masyarakat muslim juga banyak yang memegang posisi strategis dalam pemerintahan, baik sebagai praktisi maupun akademisi. Pihak Barat merasa kesulitan jika pemikiran itu lahir dari orientalis karena sudah pasti memperoleh tantangan yang besar dari umat Islam di dunia.

Nurcholish Madjid yang memiliki komitmen tinggi terhadap Islam melontarkan gagasan "Islam Yes"; Partai Islam No". Gagasan ini merupakan refleksi untuk menolak banyaknya kemunculan partai-partai Islam saat itu. Di samping itu berangkat dari kekecewaan atas partai Islam yang tidak berhasil membangun image positif dan simpatik, bahkan sebaliknya. ${ }^{16}$ Dengan kata lain, penolakan terhadap institusi kepartaian politik Islam haruslah difahami sebagai penolakan bukan karena Islamnya tetapi penolakan terhadap pemanfaatan atas Islam oleh mereka yang terlibat dalam partai Islam. Tingkah laku politik dan pemanfaatan Islam seperti itu pada gilirannya justru menjatuhkan nilai-nilai ajaran Islam yang sebenarnya. ${ }^{17}$

Namun di pihak lain, pemikiran Nurcholis Madjid tersebut menunjukkan bahwa umat Islam tidak patut mendirikan Negara Islam dengan menjadikan Islam sebagai kendaraan politiknya. Dan jargon inilah yang kemudian dijadikan oleh Pemerintah sebagai alat untuk membumihanguskan politik Islam. Sebenarnya, pemikiran ini telah terkontaminasi ${ }^{18}$ oleh rezim Orde

16 Nurcholis Madjid, Islam Kemoderenan dan Keindonesiaan (Bandung: Mizan, 1995), Cet. VIII, h. 204.

17 Nurcholis Madjid, Islam Kemoderenan dan Keindonesiaan, h. 205.

18 Yaitu kekhawatiran akan timbulnya keruncingan yang berbau SARA. Padahal istilah SARA itu sendiri adalah terminologi yang diciptakan rezim waktu itu untuk menghajar kekuatan politik umat Islam. Lihat Daud Rasyid, Reformasi Republik Sakit Peluang dan Tantangan Penerapan Syariat Islam Pasca Kejatuhan Soeharto, h. 72. 
Baru yang tidak akomodatif dengan politik Islam, di samping merupakan refleksi keinginan penguasa ${ }^{19}$ pada saat itu dan bukan disebabkan oleh bangsa Indonesia yang sangat majemuk, baik dari suku, bangsa, dan agama.

Gagasan lain yang diutarakan oleh Nurcholish Madjid mengenai sekularisasi di era 1970-an, berdampak pada kebebasan berfikir dan munculnya sikap keterbukaan di kalangan umat Islam Indonesia untuk tidak mensakralkan segala sesuatu yang bersifat material dunia, dan telah membuat masyarakat Muslim menyadari hakikat nilai pluralisme, toleransi, dan penilaian yang serba tidak absolut. ${ }^{20}$

Banyak kalangan menolak gagasan sekularisasi yang dilontarkan Nurcholis Madjid, termasuk penolakan, Harun Nasution, tokoh modernis kontemporer yang berpendidikan Barat, gagasan sekularisasi yang telah sampai ke tingkah pemisahan dunia dan akhirat. Antara kedua bentuk ini terdapat garis pemisah yang jelas. ${ }^{21}$

Sehubungan dengan hal tersebut di atas, Ibn Taymiyyah mengatakan bahwa mendirikan negara bukan perintah dari syariah, tapi menegakkan syariat Islam adalah perintah atau kewajiban. Kekuasaan harus dijalankan dengan syura dan hukum harus ditegakkan dengan adil. Kaidah ushûl fikih menyebutkan bahwa, "Mâ lâ yatim al-wâjib illâ bih, fa huwa wâjib" (sesuatu yang wajib untuk dijalankan dan kewajiban itu tidak mungkin ditegakkan kecuali adanya alat untuk sampai pada kewajiban itu). Maksudnya, menegakkan syariat Islam-yang merupakan suatu kewajiban ${ }^{22}$-haruslah secara utuh dan menyeluruh, tidak beribadah secara sempalan atau parsial, dan untuk menegakkan syariah haruslah ada sarana/alat yakni Negara. Ketika negara sudah ada, memberikan nama negara Islam atau tidak Negara Islam, bukan merupakan hal yang pokok. Yang pokok adalah melaksanakan al-amr bi al-márûf wa al-

${ }^{19}$ Indikasi lain, pemerintah juga melakukan pengebirian atau pembelengguan partai politik. Puncaknya, ketika semua parpol, bahkan ormas dipaksa untuk mengubah masing-masing asasnya menjadi asas Pancasila sebagai satu-satunya asas. Ali Murtopo, antek politik orde baru, melalui lembaga CSIS-nya, berusaha untuk membumihanguskan politik, sasaran tembak yang paling utama adalah "politik Islam". Daud Rasyid, Reformasi Republik Sakit Peluang dan Tantangan Penerapan Syariat Islam Pasca Kejatuhan Soeharto, h. 74

20 Yasmadi, Modernisasi Pesantren Kritik Nurcholis Madjid Terhadap Pendidikan Islam Tradisional (Jakarta: Ciputat Press, 2002), cet. 1 , h. 30

${ }_{21}$ Harun Nasution, Islam Rasional, (Bandung: Mizan 1996), cetakan IV, h. 193.

${ }^{22}$ Kewajiban adalah sesuatu yang harus dijalankan dalam Islam. Syariah adalah keseluruhan dari ajaran-ajaran itu sendiri. Dalam terminologi hukum pemahaman terhadap syariah baik di dalam Alquran maupun yang terkandung dalam Hadits Rasulullah Saw. mengandung suatu norma hukum sesuai yang mengalami perkembangan. Lihat Kata Pengantar Yusril Ihza Mahendra pengantar dalam Ms. Kaban, Mengawal Syariah, (Jakarta: Pustaka Ar-Raihan, 2007), h. v nahy 'an al-munkar, menciptakan kemakmuran dan perdamaian. ${ }^{23}$

\section{Faktor-faktor yang Memengaruhi Politik Hukum}

Secara konkret realitas interdependensi ekonomi Islam dan politik tersebut, dapat dibaca pada gagasan umat Islam Indonesia untuk mendirikan bank Islam, yang sangat sarat dengan muatan politis. Pada mulanya, hubungan umat Islam dan Orde Baru masih diliputi kecurigaan dan prasangka. Para penguasa Orde Baru pada 1970-an masih mencurigai gagasan tersebut sebagai salah satu wujud dari gerakan pendirian negara Islam atau realisasi Piagam Jakarta. Oleh karenanya pemerintah tidak mengizinkan pendirian lembaga tersebut. $^{24}$

Ada dua faktor secara garis besar yang memengaruhi pembentukan perbankan syariah. Pertama, ideologi. Pancasila sebagai dasar falsafah Negara Republik Indonesiamenjaminkehidupanbernegaradanberbangsa. UUD 1945 Pasal 29 yang menjamin kebebasan berkeyakinan beserta pelaksanaannya harus dipandang sebagai adanya kebebasan bagi masyarakat Islam untuk melakukan aktivitas keperdataan sesuai dengan konsep hukum Islam sebagai keyakinan yang dianut, walaupun Pasal ini masih mengalami kontroversi. ${ }^{25}$ Lahirnya UU Perbankan Syariah sebe-tulnya merupakan tuntutan ideologi Negara, dimana Negara yang mayoritas penduduknya menganut agama Islam, kebutuhan undang-undang yang mengatur ekonomi yang berbasis ajaran Islam menjadi keniscayaan.

Kedua, sebagai Negara yang penduduknya mayoritas Muslim tentu saja ajaran-ajaran Alquran dan Sunah dijadikan sebagai pedoman kehidupan (way of life) keseharian baik ibadah secara vertikal maupun secara horizontal, termasuk pemikiran dasar mengenai sistem keuangan didasarkan atas skema bagi hasil (profit and loss sharing). Islam telah memperkenalkan sistem ekonominya, sebagai solusi terhadap perekonomian dunia yang selama ini mengalami keterpurukan yang disebabkan oleh bisnis ribâwî.

Islam tidak menawarkan sistem bunga (interest). Islam mengajak para deposan untuk berpartisipasi

\footnotetext{
${ }^{23}$ Yusril Ihza Mahendra, Ms. Kaban, "Pengantar", h. viii.

${ }^{24}$ Alasan resmi yang dikemukakan Pemerintah mengenai tidak diizinkannya pendirian bank Islam adalah karena cara operasi bank Islam, yang menuntut pemerataan lebih adil dengan sistem bagi hasil, tidak sejalan dengan Undang-undang yang berlaku, yaitu Undangundang No. 14 Tahun 1967, BAB I Pasal 1, yang tidak mengizinkan beroperasinya bank tanpa bunga kredit. Lihat M. Dawam Rahardjo, "Bank Islam", dalam Ensiklopedi Islam Tematis (Jakarta: PT. Ichtiar Baru Van Houve, 2002), h. 399.

25 http://www.nggersik.com/tinjauan-politik-hukum-perbankansyariah-di-indonesia.htm, 17/02/10(Diakses pada tanggal 25 Maret 2010).
} 
dalam suatu usaha. Deposan akan mendapat bagian dari keuntungan usaha (bank) sesuai dengan rasio yang telah ditetapkan sebelumnya. Dengan demikian terjalin hubungan kemitraan antara bank dan deposan di satu pihak lain. Dan di pihak lain antara bank dan nasabah investasi yang mengelola simpanan deposan dalam pelbagai usaha produktif. ${ }^{26}$

Di dalam era pembangunan ekonomi, peranan lembaga perbankan sangat besar dan menentukan. Bank yang berdasarkan prinsip syariat Islam, diharapkan mempunyai pengaruh yang besar terhadap terwujudnya suatu sistem ekonomi Islam yang menjadi keinginan bagi setiap negara Islam atau negara yang mayoritas penduduknya beragama Islam.

Ketiga, politik kekuasaan Orde Baru. Dalam menghadapi pelbagai kecaman dan kritikan atas beragam kebijakan yang dijalankannya, pimpinan Orde Baru, Soeharto, membangun aliansi dengan partai politik, dengan harapan dapat mengerahkan dukungan rakyat terhadapnya. Ada dua partai politik yang memberikan dukungan yaitu partai NU dan PNI. NU dominan kalangan santri di kawasan perdesaan maupun wiraswasta Muslim yang merupakan mayoritas masyarakat bisnis pribumi Indonesia, serta memiliki kepemimpinan yang relatif bersatu. Di pihak lain, PNI terkenal di kalangan abangan dan pamong praja, birokrat negara yang terpenting, ${ }^{27}$ dengan melakukan pengerucutan jumlah partai-partai, Pemerintah juga (dalam hal ini golongan mayoritas anggota parlemen adalah Golkar, Wakil ABRI, Utusan Daerah, dan golongan) mengusulkan untuk menyejajarkan aliran kebatinan dengan lima agama yang ada Indonesia, dan dengan mudah mendapat persetujuan. Peminggiran keterlibatan umat Islam kembali dilakukan dengan diberlakukannya Asas Tunggal. ${ }^{28}$ Sosialisasi Pancasila dengan Program P-4 (Pedoman Penghayatan dan

${ }^{26}$ Mervyn K. Lewis \& Latifa M. Algaoud, Islamic Banking, Terjemahan oleh Burhan Subrata Perbankan Syariah Prinsip, Praktek dan Prospek (Jakarta: PT. Serambi Ilmu Semesta, 2007), Cet. I, h. 9-10

${ }^{27}$ Santri dan Abangan adalah dua istilah sosiologis yang sudah akrab di kalangan umat Islam Jawa. Secara kultural, santri digunakan untuk menyebut kelompok muslim yang taat dalam menjalankan agama. Sedangkan abangan sebaliknya, yakni sebutan untuk muslim yang tidak taat dalam menjalankan agama, terutama dalam wilayah ubudiyah. Dalam sosiologi Jawa masing-masing kelompok itu merupakan paguyuban yang seolah-olah saling membuat batas wilayah pergaulan sosiologisnya secara eksklusif. Masing-masing mempunyai budaya dan pola hubungan sosial sendiri-sendiri, sehingga nampak eksklusif. Paparan terkenal untuk pembagian dikotomi ini dapat dilihat dalam Clifford Geertz, The Religion of Java (London: The Free Press of Glencoe, 1960), h. 6.

${ }^{28}$ Setelah penerapan asas tunggal ini, semua kekuatatan politik (partai) dan semua organisasi sosial harus menjadikannya sebagai landasan ideologi partai atau organisasi. Lihat Francois Raillon, "The New Order", h. 204.
Pengamalan Pancasila) dilakukan untuk menghindari terjadinya pertentangan ideologi. Lebih dari itu, menurut Pemerintah sikap fanatisme terhadap ideologi akan mudah memancing terjadinya kerawanan dan konflik sosial, seperti peristiwa di Lapangan Banteng Jakarta ketika terjadi bentrokan antarmassa PPP dengan Golkar pada 1982.

Walaupun reaksi keras terhadap kebijakan Pemerintah ini masih tampak, seperti dalam peristiwa Tanjung Priok pada 12 September 1984, namun umat Islam menyadari bahwa perlawanan konfrontatif tidak akan berhasil. Untuk ini, kalangan cendekiawan muda melakukan reorientasi terhadap makna politik Islam yang selama ini dielaborasi dalam corak legalitas dan formalitas. ${ }^{29}$

Pada periode 1982-1985, hubungan yang baik antara Islam dan Negara mulai terwujud, walaupun belum sampai pada taraf yang ideal. Adanya Munas ketiga Golkar pada Oktober 1983, menandai awal era baru peranan politik elit Islam di dalam tubuh partai Negara Orde Baru. Akbar Tanjung sebagai kandidat Sekjen, telah memberikan harapan lebih baik bagi tokoh-tokoh gerakan Islam untuk bisa memainkan peranan lebih baik dalam tubuh Golkar di masa berikutnya. ${ }^{30}$

Keempat, ekonomi. Resesi dunia yang berkepanjangan telah mengakibatkan kemerosotan pendapatan ekspor dan arus penanaman modal asing. Padahal ekspor minyak dan penanaman modal asing bersama dengan bantuan asing, menurut Sumarlin, merupakan tiga sumber "Rezeki Nomplok". Sementara untuk menghadapi masalah baru itu beberapa masalah lama belum juga bisa diselesaikan, terutama pengangguran penduduk usia kerja yang diperkirakan tiap tahun bertambah kira-kira dua juta orang. Dalam menghadapi tantangan tersebut Pemerintah telah melakukan serangkaian kebijakan ekonomi dengan melakukan penghematan dan pengurangan anggaran belanja, reformasi perpajakan, reorganisasi bea cukai, reformasi fiskal, moneter, dan administrasi pemerintahan dengan semangat "deregulasi dan debirokratisasi". ${ }^{31}$

Kehadiran Bank Muamalat Indonesia (BMI) dalam konteks ini diharapkan bisa membantu menjawab problem ekonomi yang dihadapi Pemerintah. Krisis ekonomi yang cukup berkepanjangan akibat kelangkaan sumber pendanaan pembangunan pasca oil boom juga mendorong negara untuk menggunakan fasilitas bantuan keuangan dan kredit dari Islamic Development

\footnotetext{
${ }^{29}$ Jamhari, "Islam di Indonesia", h. 360.

${ }^{30}$ Leo Suryadinata, Golkar dan Militer (Jakarta: LP3ES, 1992), h. 21.

${ }^{31}$ Mohtar Mas'oed, Ekonomi dan Struktur Politik Orde Baru (Jakarta: LP3ES, 1989, h. 214
} 
Bank (IDB). ${ }^{32}$ Untuk mendorong pertumbuhan ekonomi serta meningkatkan kesejahteraan sosial negara-negara anggotanya yang terdiri atas 44 negara muslim di mana Indonesia termasuk di dalamnya.

Kelima, sosial. Ada dua alasan utama mengapa Orde Baru merekrut kaum muslimin. Alasan pertama dari sudut sosiologis. Sejak terbukanya akses pada pendidikan dan aktivitas ekonomi, telah memberikan para cendekiawan kesempatan untuk menempuh pendidikan di luar negeri. sepulang mereka dari menuntut ilmu disertai dengan mobilitas sosial menjadikan nilai tawar umat Islam semakin tinggi sehingga mereka harus diakomodasi ke dalam struktur Negara. Alasan kedua, peningkatan kualitas pendidikan umat Islam serta kemampuan cendekiawan Islam dalam melontarkan gagasan pemikiran Islam sehingga membuat pemerintah tidak mungkin mengabaikan keberadaan mereka, apalagi karena pemikiran-pemikiran tersebut dalam beberapa hal sesuai dengan arah dan kebijakan politik yang dikembangkan Orde Baru. ${ }^{33}$

Bentuk akomodasi pemerintah Orde Baru terhadap Islam ada empat macam, yaitu akomodasi struktural, akomodasi legislatif, akomodasi infrastruktural, dan akomodasikultural. Yang dimaksud dengan akomodasi struktural adalah diakomodasinya atau direkrutnya para tokoh Muslim pada lembaga-lembaga eksekutif (birokrasi) dan lembaga-lembaga legislatif Negara, dan didirikannya ICMI (Ikatan Cendekiawan Muslim se-Indonesia) pada 1990. Sedangkan akomodasi legislatif berkaitan dengan dikeluarkannya undangundang atau peraturan-peraturan yang berkaitan dengan Islam sebagai aturan yang mandiri dan sah. Di antara kebijakan akomodasi ini adalah pengesahan Undang-Undang Pendidikan Nasional tahun 1989, pemberlakuan Undang-Undang Peradilan Agama, diperbolehkannya pemakaian jilbab pada 1991 serta disahkannya undang-undang yang berkaitan dengan perbankan syariah di Indonesia pada 1992.

Keenam, budaya. Seperti diketahui bahwa bangsa Indonesia yang memiliki budaya hidup kebersamaan dan kegotong-royongan, sesuai dengan motivasi konstitusi terhadap perbankan syariah, itu dapat dilihat dalam Pasal 33 Ayat (4) UUD yang berbunyi, "Perekonomian Nasional diselenggarakan berdasar asas demokrasi ekonomi dengan prinsip kebersamaan,

${ }^{32}$ Hubungan IDB dan BAPINDO, Infobank, No. 53/1984, h. $16-17$

${ }^{33}$ Bachtiar Effendy, Islam dan Negara: Transformasi Pemikiran dan Praktek Politik Islam di Indonesia (Jakarta: Paramadina, 1998), h. 37-38. efisiensi, berkeadilan, berkelanjutan, berwawasan lingkungan, kemandirian, serta dengan menjaga keseimbangan kemajuan dan kesatuan ekonomi Nasional."

Institusi ekonomi yang paling tepat untuk menerjemahkan hal di atas adalah perbankan syariah, karena: (1) sesuai dengan aspirasi masyarakat serta sangat tepat untuk masyarakat Indonesia yang sebagian besar menjadi pelaku usaha mikro, kecil, dan menengah (asas demokrasi ekonomi); (2) Perbankan syariah mengutamakan kemajuan bersama daripada kemajuan individu (asas kebersamaan); (3) Perbankan syariah sangat cocok sebagai solusi pembiayaan untuk masyarakat kecil sehingga mereka dapat menikmati layanan perbankan dan dapat memberdayakan diri (asas keadilan dan kemandirian); (4) Perbankan syariah tidak boleh mendukung atau bermitra dengan pengusaha atau perusahaan yang terlibat dalam kerusakan lingkungan (asas keberlanjutan dan lingkungan); (5) Perbankan syariah menggabungkan antara tuntutan duniawi dengan tuntutan ukhrawi (asas keseimbangan); dan (6) Perbankan Syariah sangat mengutamakan kemajuan sektor riil, yang sangat cocok dengan ekonomi nasional yang berbasis pada sumber daya alam dan sumber daya manusia (asas kesatuan ekonomi nasional dan kegotongroyongan)..$^{34}$ Sejalan dengan tujuan pembangunan nasional Indonesia untuk mencapai terciptanya masyarakat adil dan makmur berdasarkan demokrasi ekonomi, perlu dikembangkan sistem ekonomi yang berlandaskan pada nilai keadilan, kebersamaan, pemerataan, dan kemanfaatan.

Dalam konteks eksternal, berdirinya IDB ini kemudian memberikan pengaruh bagi berdirinya. Bank-bank Islam di seluruh dunia, termasuk Indonesia, bank Islam pertama, Bank Mu'amalat Indonesia (BMI), baru bisa didirikan pada 1991, padahal pemikiran mengenai hal ini sudah terjadi sejak dasawarsa '70-an. Penghalangnya adalah faktor politik, yaitu bahwa pendirian bank Islam dianggap sebagai bagian dari cita-cita mendirikan negara Islam. Di kawasan Eropa seperti di Timur Tengah, bank-bank Islam bermunculan pada belahan kedua dasawarsa '70-an, misalnya Dubai Islamic Bank (1975) dan Kuwait Finance House (1977). Di Iran, islamisasi sistem perbankan dilakukan secara Nasional setelah berdirinya Republik Islam Iran. Di Asia Tenggara, tonggak perkembangan perbankan terjadi pada awal

${ }^{34}$ Zubaisri Hasan, Undang-Undang Perbankan Syariah, Titik Temu Hukum Islam dan Hukum Nasional (Jakarta: Rajawali Press, 2009), h. 11-12. 
dasawarsa '80-an, dengan berdirinya Bank Islam Malaysia Berhad (BIMB) pada 1983, yang menjelang tahun 2000 telah mengembangkan 70 cabang di seluruh Malaysia. BIMB sekses terutama berkat kerjasama dengan Lembaga Urusan dan Tabung Haji. Sukses BIMB itu mendorong lahirnya bank-bank Islam serupa. ${ }^{35}$

Ketujuh, politik eksternal. Faktor pendorong berdirinya perbankan syariah ini dari kenyataan bahwa negara-negara Muslim khususnya, dan negara sekuler umumnya telah membuka dan mengoperasikan bank prinsip bagi hasil. Untuk itu, Indonesia sebagai negara muslim terbesar di dunia merasa tergugah dan terbuka pandangannya bahwa Indonesia telah banyak memperoleh bantuan dari bank Islam di dunia.

Setelah didirikannya bank syariah di Indonesia, IDB memberikan bantuan keterampilan teknis kepada calon pengelola Bank Muamalat Indonesia, juga mensponsori kajian-kajian/seminar yang dibutuhkan untuk pendirian bank syariah di Indonesia. Khusus bantuan-bantuan yang diberikan IDB yang tertuang dalam anggaran dasarnya, Pasal 2 Ayat (xi) pada butir 103 berbunyi, "IDB memberikan bantuan teknis, baik dalam bentuk penyelenggaraan seminar-seminar ekonomi dan perbankan syariah seluruh dunia maupun dalam bentuk pembiayaan untuk tenaga perbankan yang belajar di bank syariah serta tenaga ahli bank syariah yang baru berdiri”. ${ }^{36}$

Kedelapan, ekonomi. Masyarakat dunia Islam menginginkan keluar dari jeratan pengaruh yang mencengkeram dari sistem kapitalisme. Serangkaian krisis bertubi-tubi yang dialami sistem keuangan internasional sepanjang dua dekade terakhir-yang telah memunculkan kesadaran baru akan kebutuhan reformasi arsitektur sistem keuangan juga telah memberikan angin segar bagi pengembangan sistem keuangan Islami. Sistem keuangan islami diharapkan mampu menyuntikkan disiplin sekaligus mendorong untuk terpenuhinya regulasi dan supervisi yang prudensial pada industri keuangan. ${ }^{37}$ Peristiwa krisis minyak 1974 dan 1979-yang menimbulkan kekuatan finansial, berupa petro-dolar pada negaranegara di kawasan Timur Tengah dan Afrika Utara, termasuk Indonesia, Malaysia, dan Brunei di Asia Tenggara-merupakan faktor pendorong hubungan ekonomi dunia.

\footnotetext{
${ }^{35}$ A. Riawan Amin, Manata Perbankan Syariah di Indonesia, h. 87

36 Karnaen Perwataatmaja dan Syafii Antonio, Apa dan Bagaimana Bank Islam, h. 67.

${ }^{37}$ M. Umer Chapra \& Habib Ahmed, Corporate Governance in Islamic Financial Institution (Jeddah: Ocasional Paper IDB, 2002), h. 1
}

\section{Pengesahan RUU Perbankan Syariah Menjadi Undang-Undang}

Pasal 20 ayat (4) dan ayat (5) UUD Negara Republik Indonesia 1945 setelah perubahan, menyatakan, "Presiden mengesahkan rancangan undang-undang yang telah disetujui bersama untuk menjadi undangundang". Sebagaimana diatur dalam ketentuan Pasal 20 ayat (5) yang menyatakan, "Dalam hal rancangan undang-undang yang telah disetujui bersama tidak disahkan oleh Presiden dalam waktu tiga puluh hari semenjak rancangan undang-undang tersebut disetujui, rancangan undang-undang tersebut sah menjadi undang-undang dan wajib diundangkan". Sebuah RUU yang sah menjadi undang-undang karena lewat waktu 30 (tigapuluh) hari sejak RUU tersebut disetujui bersama, tidak memerlukan perbuatan Presiden lagi atau dapat dikatakan RUU tersebut sah demi hukum telah berubah menjadi undang-undang.

Dewan Perwakilan Rakyat (DPR) mensahkan Rancangan Undang-Undang Perbankan Syariah menjadi Undang-undang dalam rapat paripurna yang dipimpin oleh ketua DPR, Agung Laksono di ruang Rapat Paripurna, Gedung Nusantara II, Selasa 17 Juni 2008. Beberapa fraksi dalam pandangannya menilai perbankan syariah dapat memberi kontribusi bagi perekonomian nasional. ${ }^{38}$

Juru bicara F. PAN, Nurul Falah, mengutarakan pendapatnya bahwa pada saat ini Perbankan Syariah telah memberikan kontribusi yang signifikan dalam upaya menumbuhkembangkan sistem ekonomi yang berlandaskan pada nilai keadilan. Di samping itu, ia menilai bahwa keberadaan Perbankan Syariah memberikan sumbangsih yang cukup signifikan pula untuk menggerakkan pelbagai sektor perekonomian Indonesia, terutama sektor usaha menengah, kecil, dan mikro.

Sedangkan juru bicara F-PKB, Arsa Suthisna menilai bahwa perbankan syariah yang masih berusia muda tentu saja masih mempunyai kelemahan terutama pada keterbatasan kualitas dan kuantitas sumber daya manusia. Untuk itu perbankan syariah harus mempersiapkan sumber daya yang mumpuni yang memiliki integritas, moralitas serta komitmen yang tinggi. Selanjutnya dia meminta agar dilakukan sosialisasi terhadap perbankan syariah, karena pemahaman masyarakat masih sangat rendah terhadap produk maupun perbedaannya dengan perbankan konvensional.

\footnotetext{
${ }^{38}$ dpr.go.id, tanggal 18 Juni 2008, h. 1
} 
Tukijo, juru bicara F-PDIP, menilai bahwa 'perbankan syariah mengalami peningkatan yang pesat dan mendapat respons positif dari pihak industri jasa perbankan. Untuk itu perbankan syariah tidak boleh berdiri secara eksklusif, membatasi pihak yang terkait dengan penggunaan jasa Perbankan Syariah, melainkan harus terbuka untuk kepentingan semua lapisan masyarakat.

F-PG, melalui juru bicaranya, Harry Azhar Aziz menjelaskan bahwa orientasi dalam UU Perbankan Syariah adalah pada stabilitas sistem dengan mengadopsi 25 Based Core Principles for Effective Banking Supervision terutama terkait dengan perizinan, prudential, kewajiban pengelolaan risiko, pembinaan dan pengawasan, dan jejaring pengaman sistem perbankan syariah. Fraksi ini juga menilai dengan adanya prinsip tersebut maka RUU Perbankan Syariah akan memiliki aspek kepatuhan syaria, perlindungan konsumen, kenyamanan iklim investasi, dan kepastian usaha serta stabilitas perbankan secara keseluruhan.

Menurut F-PPP, dengan juru bicaranya Sofyan Usman, keberadaan UU Perbankan Syariah sudah sangat mendesak dan telah lama dinanti-nanti pelbagai kalangan karena Perbankan Syariah di Indonesia sudah cukup lama beroperasi dan mengalami perkembangan yang sangat pesat. Ini menunjukkan adanya minat pelbagai kalangan dalam menggunakan jasa perbankan syariah sehingga harus dijawab dengan memberikan ruang yang semakin terbuka dan berkembang.

Tata Zainul Muttaqin dari F-PD menilai bahwa Perbankan Syariah merupakan salah satu wujud untuk memulihkan perekonomian Nasional melalui investasi dalam dunia perbankan syariah, khususnya investasi dari luar negeri terutama negara-negara di kawasan Timur Tengah. Oleh karena itu perlu pengaturan yang lebih rinci dan lebih jelas lagi tentang perbankan syariah. ${ }^{39}$

F-FBR dengan juru bicara, Zainul Abidin, menjelaskan bahwa siapa saja dapat memanfaatkan jasa keuangan bank syariah. Ketika krisis moneter melanda Indonesia pada pertengahan 1997, sistem syariah telah memberikan manfaat bagi banyak kalangan. Ini menjadi salah satu fakta bahwa bank syariah di Indonesia memberikan kontribusi signifikan bagi ketahanan dan pertumbuhan perekonomian negara.

Sedangkan F-PKS, melalui juru bicara Mustafa Kamal, berharap dalam pelaksanaan perbankan syariah harus diikuti dengan keberpihakan yang lebih besar dan nyata dalam hal penyaluran dana bagi usaha kecil dan menengah serta kemudahan akses dana bantuan bagi UMKM. Sehingga mampu menggerakkan sektor riil dan memiliki manfaat yang lebih besar bagi terciptanya

\footnotetext{
39 dpr.go.id, tanggal 18 Juni 2008, h. 2 (Diakses Tanggal 21 Februari 2010)
}

kemakmuran dan kesejahteraan rakyat.

Lebih sederhana lagi pandangan dari F-BPD menyatakan setuju RUU ini disahkan menjadi UndangUndang.

Namun demikian, tidak semua Fraksi menyetujui UU Perbankan Syariah disahkan menjadi UU. Dari 10 fraksi yang ada di DPR, satu di antaranya F-PDS menolak RUU Perbankan Syariah disahkan, dengan alasan bahwa perbankan syariah tidak sesuai dengan hukum dasar Indonesia yaitu Pancasila dan UUD NRI 1945. Fraksi tersebut, melalui juru bicaranya, Retna Rosmanita Situmorang, menyampaikan bahwa infor-masi di beberapa negara yang ia ketahui, terbukti bahwa produk Perbankan Syariah tidak dalam bentuk undang-undang, hanya merupakan turunan dari undang-undang perbankan yang ada, bukan dalam undang-undang yang khusus. ${ }^{40}$

Dari pihak Pemerintah, Menteri Agama, Maftuh Basyuni, berharap dengan disahkannya UU Perbankan Syariah dapat mendorong industri perbankan dalam negeri untuk tumbuh dan berkembang lebih baik.

\section{Penutup}

Perjuangan umat Islam terhadap pembangunan hukum perbankan syariah di Indonesia telah dirintis sejak negara Republik ini berdiri. Perjuangan keras yang tidak mengenal lelah telah memberikan hasil yang nyata bagi pembentukan perbankan syariah yang sekarang telah eksis di bumi pertiwi. Dalam pembentukan perbankan syariah telah terjadi sinergisitas antara rakyat dan pemerintah Indonesia. Hal ini terlihat dari pelbagai faktor yang memengaruhi terbentuknya hukum perbankan syariah di Indonesia yakni, faktor idiologi, agama, politik, sosial, dan budaya. Sikap akomodatif Pemerintah terhadap umat Islam, baik dalam bentuk struktural, infrastruktural, legislatif, dan kultural juga merupakan bukti nyata bahwa umat Islam telah berhasil melakukan pendekatan terhadap Pemerintah. []

\section{Pustaka Acuan}

Ahmad, Ma’sum, Politik Hukum Kekuasaan Kehakiman Pasca Amandemen Undang-undang Dasar 1945, Yogyakarta: Total Media, 2009.

Alfian, Pemikiran dan Perubahan Politik Indonesia, Jakarta: Gramedia, 1978.

Ali, Mohammad Daud, Hukum Islam di Peradilan Agama (Kumpulan Tulisan) Jakarta: Raja Grafindo Persada, 2002.

Allouche, Adel, Maluk Ekonomics: Astudy and Translation of al-Maqrizi's Ighathah Salt Lake City: University of

${ }^{40}$ dpr.go.id, tanggal 18 Juni 2008, 3. , 2 (Diakses Tanggal 21 Februari 2010) 
Utah Press, 1994.

Amin, Ma' ruf, Fatwa dalam Hukum Sistem Islam, Jakarta: Elsas, 2008.

Arifin, Busthanul, Pelembagaan Hukum Islam di Indonesia: Akar Sejarah dan Prospeknya, Jakarta: Gema Insani Press, 1996.

As-Shawi, al-Shalah, \& Al-Mushlish, Abdullah, Fikih Ekonomi Keuangan Islam, Penerjemah Umar Ibnu Basyir, Jakarta: Darul Haq, 2008.

Azhari, Muhammad Tahir, Negara Hukum Suatu Studi tentang Prinsip-prinsipnya Dilihat dari Segi Hukum Islam. Implementasiny pada Priode Negara Madinah dan Masa Kini, Jakarta: Bulan Bintang, 1992.

Chatamarrasyid, Hukum Perbankan Nasional Indonesia, Jakarta: Kencaba Prenada Media Group, 2008.

Dahlan, Abdul Aziz, dkk (ed), Ensiklopedi Hukum Islam, Jakarta: Ichtra Baru Van Hoeve, 1997.

Daniel S. Lev, Islamic Court in Indonesia, Berkeley, LA: University of California Press, 1972.

Deliarnov, Perkembangan Pemikiran Ekonomi, Jakarta: Rajawali Press, 1995.

Dewan Syariah Nasional (DSN) MUI, Himpunan Fatwah Dewan Syariah Nasional, Jakarta : DSNMUI dan BI, 2003.

Ghazali, Aidit, Islamic Thinkers on Economics, Administration, and Transactions, Kuala Lumpur: Quil Publisher, 1991.

Ghazanfhar, S.M. dan Islahi, Abdul Azim, Economic Thought of an Arab Scholastic: Abu Hamid al-Ghazâlî, dalam History of Political Economy, Durham: Duke University Press, 1990.

Halim, Abdul, Politik Hukum Islam di Indonesia, Ciputat: Ciputat Press, 2005.

Hamdan, M., Politik Hukum Pidana, Jakarta: Raja Grafindo Persada, 1997.

Hanief, M. Assalam, Contemporary Islamic Economic Thought: A Selected Comparative Analysis, Kuala Lumpur: 1995.

Hartono, Sunaryati, Politik Hukum Menuju Satu Sistem Hukum Nasional, Bandung: Alumni, 1991.

Haryatmoko, Etika Politik dan Kekuasaan, Jakarta: Penerbit Buku Kompas, 2004.

Hasjimi, Sejarah Kebudayaan Islam, Jakarta: Bulan Bintang, 1987.

Hession, Charles, "The development of Economic Ideas" dalam Arthur L. Grey dan Jhon E. Elliot (eds), Economic Issues and policies: Reading in Introductory Economics, USA: Houghton Mifflin Company, 1961.

Janidal, al-, Hammâd ibn 'Abd al-Rahmmân, Manâhij al-Bahitsin fi al-Iqtishâ al-Islâmi, Riyâdh: Syirkah alUbaykan li al-Thabâ’ah wa-al Nasyir, 1406 H.

Karim, Adiwarman Azwar, Pemikiran Ekonomi Seorang
Skolastik Arab: Abu Hamid Al-Ghazali, Jakarta: Tim IIIT IAIN Jakarta, 2002.

-.--.--.--., Sejarah Pemikiran Ekonomi Islam, Jakarta:

PT. RajaGrafindo Persada, 2004.

Kusumah, Mulyan W. dan Baut, Paul S., Hukum, Politik dan Perubahan Sosial, Jakarta: Yayasan Lembaga Bantuan Hukum Indonesia, 1988.

Lev, Daniel S., Peradilan Agama Islam di Indonesia, alih Bahasa Zaini Ahmad Noeh dari judul asli, Islamic Courts in Indonesia: A Study in the Political Bases of Legal Institutions, Jakarta: Intermasa, 1986.

Mahfud MD, Moh., Pergulatan Politik Hukum di Indonesia, Yogyakarta: Gama Media, 1999.

..-.-.-.-.-, Politik Hukum di Indonesia, Jakarta: Rajawali Press, 2009.

Maqrizi, al-, Al-Nuqûdal-Qâdimah al-Islâmiyyah, dalam al-Abbal-insitas al-Karmali (ed) Kitâb an-Nuqûud al-Arabiyah wa al-Islâmiyyah wa 'Ilm an-Namyat, alQâhirah: Maktabah al-Tsaqâfah al-Dîniyyah, 1986.

Nasution, Mustafa Edwin, et al, Pengenalan Eklusif Ekonomi Islam, Jakarta: Kencana, 2007.

Nyazee, Imran Ihsan Khan, Theories of Islamic Law, Delhi: Adam Publishers \& Distributors, 1966.

Perwataatmadja, Karnaen, dan Antonio, Muhammad Syafi' i, Apa dan Bagaimana Bank Islam, Yogyakarta: PT. Dana Bhakti Prima Yasa, 1999.

-..--.-.-.-., "Sejarah Pemikiran Ekonomi Islam", Diktat Kuliah pada Fakultas Syariah, 2000/2001.

Qureisyi, Anwar Iqbal, Islam and The Theory of Interest, Lahore: S.M. Ashraf Publishers, 1946.

Radhie, Pembangunan Hukum Nasional dalam Perspektif Kebijaksanaan dalam Artidjo Alkostar (ed), Identitas Hukum Nasional, Yogyakarta: Fakultas Hukum UII, 1997.

Rahardjo, M. Dawam, "Kata Pengantar Menegakkan Syariat Islam di Bidang Ekonomi", dalam Adiwarman A. Karim, Bank Islam: Analisis Fiqih dan Keuangan, Jakarta: Raja Grafindo Persada, 2007.

Rahardjo, Satjipto, Membangun dan Merombak Hukum Hukum Indonesia Sebuah Pendekatan Lintas Disiplin, Yogyakata: Genta Publishing, 2009.

Rajagukguk, Erman, "Perubahan Hukum di Indonesia Persatuan Bangsa, Perubahan Ekonomi dan kesejahteraan sosial (1998-2004)". Makalah disampaikan dalam seminar Hukum di Indonesia, dilaksanakan di Fakultas Hukum Universitas Indonesia pada tanggal 17 Desember 2004 di Jakarta.

Rasjidi dan Putra, I.B. Wyasa, Hukum Sebagai Suatu Sistem, Bandung: Remaja Rosdakarya, 1993.

Sadeq, Abdul Hasan M. dan Ghazali, Aidit (ed), Reading in Islamic Thought, Malaysia: Longman, 1992.

Salabi, Ahmad, Sejarah dan Kebudayaan Islam, Jakarta: 
Pustaka al-Husna, 1994.

Saragih, Bintan Ragen, Politik Hukum, Bandung: CV. Utomo, 2006.

Schacht, Joseph, An Introduction to Islamic Law, Oxford: Oxford University Press, 1964.

Sidiqi, M. Nejjatullah, The History of Islamic Economic Thought, dalam Ausaf Ahmad dan Kazim Raza
Awan, Lectures on Islamic Economics, Jeddah: IRTI, IDB, 1992.

Soekanto, Soejono, Pokok-Pokok Sosiologi Hukum, Jakarta: Rajawali Press, 1991.

Mertokusumo, Sudikno, Mengenal Hukum, Suatu Pengantar, Yogyakarta: Leberty, 1991. 